Narodowa Akademia Nauk Białorusi Mińsk

https://orcid.org/0000-0003-0896-8553

\title{
Niematerialne dziedzictwo kulturowe w warunkach pandemii COVID-19. Analiza porównawcza wybranych przykładów z Polski i Białorusi ${ }^{1}$
}

Trwająca w 2020 roku światowa pandemia COVID-19 ma wpływ na kulturę, zwłaszcza na te jej dziedziny, których istnienie stanowi ważny element tożsamości kulturowej zarówno wspólnot lokalnych, jak i społeczeństwa określanego mianem naród. Pod tym względem ujawnia się problem bezpieczeństwa kulturowego, który ma wymiar społeczno-kulturowy, polegający na utrwalaniu i umacnianiu składników decydujacych o ciagłości tożsamości kulturowej, a więc tych, które zaliczyć można do tradycji kulturowych narodu $i$ społeczności regionu (kontynentu) lub innego podmiotu bezpieczeństwa ${ }^{2}$. Zarazem wymiar państwowo-instytucjonalny bezpieczeństwa kulturowego zakłada szczególną potrzebę otaczania opieką ciągłość tradycji przez państwo w sytuacjach zagrożenia. W związku z tym na plan pierwszy wysuwa się dziedzictwo niematerialne, którego ciągłość stanowi rdzeń tożsamości społeczności lokalnych.

Dziedzictwo niematerialne $\mathrm{w}$ dobie pandemii jest w centrum uwagi międzynarodowej. W kwietniu 2020 r. UNESCO uruchomiła online ankiete w celu zebrania informacji o doświadczeniach, związanych z żywymi lokalnymi tradycjami na całym świecie w kontekście COVID-19³ . Wnioski

1 Artykuł został przygotowany w ramach Programu Stypendialnego Polskiego Komitetu ds. UNESCO pod kierownictwem naukowym dr hab. Katarzyny Smyk w Instytucie Nauk o Kulturze UMCS.

2 Z. Ścibiorek, Uwarunkowania zachowań ludzkich w sytuacji zagrożenia, [w:] Społeczeństwo a wojna: oblicza bezpieczeństwa w XX i XXI wieku, Wrocław 2016, s. 13.

3 Living Heritage Experiences and the COVID-19 Pandemic, [online], https://ich.unesco. org/en/living-heritage-experiences-and-the-covid-19-pandemic-01123, [dostęp 08.11.2020]. 
wyciągnięte na podstawie tych danych pokazują, że w większości przypadków dziedzictwo niematerialne zostało dotknięte przez pandemię ${ }^{4}$. Można z pewnością twierdzić, że oddziaływanie pandemii na ten wrażliwy, a wręcz zagrożony obszar kultury zostanie tematem badań, które będą mnożyć się wraz z przebiegiem samej pandemii. W tym artykule skupimy się szczegółowo na wpływie COVID-19 na dziedzictwo niematerialne dwóch krajów ościennych - Polski i Białorusi.

\section{Obszar badań i metodologia}

Zamysł artykułu początkowo polegał na porównaniu strategii działań, które powstały w dobie pandemii w sferze ochrony dziedzictwa niematerialnego w Polsce i na Białorusi na przykładach wybranych zjawisk. Jednak różnica $\mathrm{w}$ podejściu do zagrożenia pandemicznego sprawiła, iż w dalszym obiegu tego rodzaju porównania okazały się nie w pełni możliwe. Odrębności wynikają z rekomendacyjnego charakteru środków zapobiegających rozprzestrzenianie się koronawirusa prawie do listopada 2020 r. na Białorusi ${ }^{5}$, podczas gdy w Polsce od marca 2020 obowiązują różnego rodzaju restrykcje, które zostały rozłożone na kilka etapów.

Mimo różnicy w traktowaniu pandemii zaproponowane do analizy elementy dziedzictwa niematerialnego - tradycja Bożego Ciała z kwietnymi dywanami w Spycimierzu; perebory - nadbużańskie tradycje tkackie (Polska); korowodowy obrzęd na święto Jurja we wsi Pahost; pereborne tkactwo w Homlu (Białoruś); oraz dwa festiwale - Festiwal Kapel i Śpiewaków Ludowych w Kazimierzu nad Wisłą (Polska) i Festiwal Sztuki Ludowej „Бepaгіня” („Berahinia”) w miasteczku Akciabrski (Białoruś) - zostały poddane analizie na pewnych płaszczyznach: wpływ pandemii na kontynuację tradycji lub organizację wydarzeń, wprowadzone zmiany i stosunek lokalnej wspólnoty depozytariuszy do zmian.

W artykule szczególnie brany jest pod uwagę wymiar społeczno-kulturowy pandemii i towarzyszące jej formy środków dystansowania społecznego. Są one czynnikiem warunkującym życie człowieka w dobie zagrożenia i doprowadzają do tego, że osoba внезапно обнаруживает себя изолированньм почти от всех своих близких, часто даже от членов соб-

4 Living Heritage Experiences and the COVID-19 Pandemic: Snapshot of the UNESCO Online Survey, [online], https://ich.unesco.org/doc/src/8GA-snapshot_on_survey_living_ heritage_pandemia-EN.pdf, [dostęp 29.11.2020].

5 Ograniczenia dotyczyły jedynie organizacji pogrzebu zmarłych z powodu COVID-19. 
ственной семьи. Болезнь погружает жертву в состояние некоего соииального вакуума 6 . Mają bezpośredni wpływ na funkcjonowanie przedmiotu badania: środki zapobiegające rozprzestrzenianiu się pandemii w postaci tzw. izolacji czy konieczności zachowania dystansu (social distancing), wpływają na ciągłość dziedzictwa niematerialnego, modele przekazu, ponieważ jego żywotność opiera się na bezpośredniej komunikacji depozytariuszy. Te czynniki często uniemożliwiają również kontynuowanie dotychczasowych form ochrony niematerialnego dziedzictwa, jednakże stymulują depozytariuszy oraz centralne i lokalne instytucje czy organizacje do podejmowania nowych form zapobiegania zanikowi tego dziedzictwa.

Na potrzeby badania były przeprowadzone wywiady (na żywo, online i drogą telefoniczną) z depozytariuszami dziedzictwa niematerialnego (październik 2020, Husinka, Polska) oraz przedstawicielami instytucji państwowych i pozarządowych zaangażowanych $\mathrm{w}$ proces zachowania niematerialnego dziedzictwa kulturowego (październik 2020, Lublin, Polska; grudzień 2020 Homel, Białoruś). Materiałem badawczym również stały się wywiady nagrane podczas realizacji projektu „Procesja Bożego Ciała z tradycją kwietnych dywanów w Spycimierzu - ochrona i wzmacnianie tradycji" (czerwiec 2020, Spycimierz) ${ }^{7}$ i udostępnione przez Miejsko-Gminną Bibliotekę Publiczna w Uniejowie. Wywiady były przeprowadzone w języku polskim i białoruskim, nagrane i następnie transkrybowane.

W zebranych materiałach w wypowiedziach respondentów obecny jest wątek strachu i lęku. Strach przed zakażeniem stał się częścią życia depozytariuszy dziedzictwa podczas pandemii. Wspólnota lokalna Spycimierza, gdzie co roku obchodzone jest w wyjątkowy sposób Boże Ciało ${ }^{8}$, podkreśla wpływ strachu na ogólną atmosferę tradycji w 2020 r.: Myśle, że ludzie byli przestraszeni, kiedyś pamiętam, nawet dwa lata temu jak byt biskup

6 П. Сорокин, Человек и общество в условиях бедствий. Влияние войньи, революиии, голода, эпидемии на интеллект и поведение человека, сочиальную организачию и культурную жизнь, Санкт-Петербург 2012, с. 23.

7 Projekt trwal 2 lata i obejmował badania etnograficzno-antropologiczne i społeczno-przestrzenne oraz warsztaty, seminaria, wyjazd studyjny. Raport z wyników projektu jest pierwszym opracowaniem w Polsce, które oprócz analizy zagrożeń dla określonego elementu niematerialnego dziedzictwa kulturowego zawiera również rekomendacje dotyczące planu jego ochrony, skierowane do depozytariuszy tradycji. Autorem projektu jest dr hab. Katarzyna Smyk, profesor Uniwersytetu Marii Curie-Skłodowskiej (Procesja Bożego Ciała z tradycją kwietnych dywanów w Spycimierzu Raport z badań i rekomendacje do planu ochrony, red. Katarzyny Smyk, Uniejów-Wrocław: Miejsko-Gminna Biblioteka Publiczna w Uniejowie, Polskie Towarzystwo Ludoznawcze, 2020).

8 K. Smyk, Obrzęd jako tekst kultury. Przyktad Bożego Ciała w Spycimierzu, Lublin 2020 . 
z Lowicza to ludzie ptakali na kazaniu, była taka rodzinna atmosfera, byli blisko ludzi. Teraz byty te dwa metry, ludzie ze strachu to nawet maseczki nosili, wiadomo gdzieś tam ta atmosfera prysta $w$ tegorocznych obchodach (Spycimierz KG 2020 AJ). Obawy dotyczyły udziału w masowych elementach praktyki: (...) nie przy uktadaniu drogi, ale na msze, że będzie za dużo ludzi $i$ wziętam ze soba maseczke, ale staliśmy w takiej odległości, że nie było to konieczne (Spycimierz NN 2020 AJ). Strach wpływał na decyzje o uczestnictwie w tegorocznych obchodach: Ktoś powiedziat - moje zdrowie ważniejsze jest, bo takie stowa padały, że ja nie będe narażat życia. Proszę bardzo, nie narażaj. Nawet ich nie było. Jak za dawnych czasów szła procesja, a oni stanęli gdzieś z boku albo wcale nie przyszli $i$ tyle (Spycimierz TP $2020 \mathrm{KS}$ ). Ponadto pandemia wywołała egzystencjalny lęk, powiązany z obawami o los tradycji: Bałam się, że w ogóle nic nie będzie przez pandemie, jeszcze miesiac temu. Jak by nie byty poluzowane te obostrzenia, że można bez maseczek chodzić $i$ w ogóle wychodzić, to nie przeżyje tego Bożego Ciała (Spycimierz JR 2020 AWB). W związku z tymi podstawowymi koncepcjami teoretycznymi dla badania są koncepcje związane ze strachem i lękiem. Strach w poszczególnych naukach (psychologii, psychiatrii, filozofii, socjologii) różni się od lęku. Odrębności polegają na tym, że źródłem pochodzenia strachu jest środowisko zewnętrzne, natomiast lęk ma początki wewnątrz osoby, jest bardziej niebezpieczny od uczucia strachu ${ }^{9}$. Jednak ze względu na powiązanie tych dwóch zjawisk - stanów emocjonalnych jednocześnie pojawiających się w sytuacji zagrożenia - te dwa terminy są w tym artykule wykorzystywane synonimicznie.

Zastosowano jakościową metodę analizy tekstów wywiadów z przedstawicielami społeczności lokalnych i organizacji działających m.in. na rzecz ochrony dziedzictwa niematerialnego Polski i Białorusi. Użyto metody rekonstrukcji i analizy wydarzeń na podstawie danych tekstowych i analizy treści materiału faktologicznego zebranego przy pomocy kwerendy internetu. Badanie również polega na wykorzystaniu metody analizy porównawczej oraz innych metod i podejść stosowanych w naukach pokrewnych, jak na przykład w kognitywistyce, która ujmuje strach jako narzędzie doświadczeń rzeczywistości ${ }^{10}$.

9 J. SJ Bremier, Co kognitywistyka może nam powiedzieć o lęku i strachu?, [w:] Anatomia strachu. Strach, lęk i ich oblicza we wspótczesnej kulturze, Kraków 2017, s. 28.

10 Tamże, s. 40. 


\section{Podstawowe koncepcje teoretyczne}

Globalne epidemie - pandemie - i epidemie z lokalnymi ogniskami rozprzestrzeniania towarzyszą ludzkości przez całe jej istnienie. Pojawiają się one mimo rozwoju medycyny, przełomów technologicznych, zmian w sposobie życia ludzi i podstaw społeczno-kulturowych. Postęp cywilizacyjny nie pozwala w pełni uniknąć zagrożenia epidemiologicznego i związanej z nim sytuacji kryzysowej, tak jak nie pozwala przezwyciężyć atawistycznego lęku przed każdą umowną „zarazą" ${ }^{11}$, opartego na zbiorowej traumie, zakorzenionej w czasach „czarnej zarazy” z lat 1347-1352 w Europie ${ }^{12}$.

Pandemia COVID-19 (jak i każda inna) jest traktowana jako czas, w którym zwykły tryb życia się zmienia. Przyczynia się ona do pojawienia tzw. Nowej normalności, gdy wprowadzone zmiany stają się na początku nowym, a później - zwykłym niezbędnym znakiem codzienności, jej normą. Według Debory MacKenzie poprzednia „norma” musi odejść do przeszłości, ponieważ to właśnie ona nas do tego [pandemii - aut.] doprawadziła, a kontynuacja tego stanu oznacza kolejne pandemie, z niemałym prawdopodobieństwem znacznie gorsze ${ }^{13}$. Na swój sposób traktuje nową normalność autor książki „Wspólnota i zagrożenie: wrocławianie wobec wielkiej powodzi: socjologiczny przyczynek do analizy krótkotrwałej wspólnoty" - Wojciech Sitek. Według autora jest ona nowym ładem społecznym, który powstał na skutek oswajania strachu oraz procesu odnajdywania się w sytuacji kryzysowej i rozpowszechnia się na każdą stronę życia ludzi. Nowy ład opiera się na pewnym układzie wartości i norm, jak i na strategiach grup społecznych. Akceptowany jest przez członków społeczności, nawet gdy jego elementem są konflikty i zagrożenia, stające się dla tej społeczności zagrożeniami zwyktymi ${ }^{14}$,

Pandemia wywołała uczucie braku bezpieczeństwa, lęk, strach, które znalazły się w strukturze nowej normalności. Znaczenie strachu dla człowieka jest bardzo duże. Według Zygmunta Freuda właśnie strach spowodował stworzenie przez ludzi kultury ${ }^{15}$. Z kolei Ulrich Beck podkreśla, że

11 B. Tuchman, Odległe zwierciadto czyli rozlicznymi plagami nękane XIV stulecie, Katowice 1993, s. 99-128.

12 M. Vovelle, Śmierć w cywilizacji Zachodu: od roku 1300 po wspótczesność, Gdańsk 2004, s. 107.

13 D. MacKenzie, COVID-19: pandemia, która nie powinna byla się zdarzyć, i jak nie dopuścić do następnej, Poznań 2020, s. 259.

14 W. Sitek, Wspólnota i zagrożenie: wrocławianie wobec wielkiej powodzi: socjologiczny przyczynek do analizy krótkotrwatej wspólnoty, Wrocław 1997, s. 6, 18.

15 Z. Freud, Pisma spoteczne. Dzieła, Warszawa 1998, tom IV. 
człowieczeństwo na przełomie XX i XXI wieku stało się społeczeństwem ryzyka, które wprawiane jest $w$ ruch zdaniem: boje się!16. Jurij Łotman nazywa strach wraz ze wstydem psychologicznym mechanizmem kultury, który reguluje ograniczenia narzucane człowiekowi przez kulturę ${ }^{17}$.

Lęk można traktować ambiwalentnie w zależności od jego ilości i siły: w małej dawce oddziałuje integrująco na grupę społeczną, natomiast w dużej ilości ma efekt odwrotny - wywołuje chaotyczne działania, bezcelowe i impulsywne zachowanie ${ }^{18}$. Lęk społeczny w małej dawce ułatwia człowiekowi podjęcie decyzji uwarunkowanej zbyt wieloma czynnikami i pomaga w ustaleniu hierarchii wartości ${ }^{19}$, co powoduje, że zarówno jak i strach może on być produktywny. Produktywność polega na tym, że emocje te wzbudzają reakcje, inspirują do działania: Konstatacja „ta sytuacja jest straszna” jest opisem pewnej uczuciowej atmosfery, która obiektywnie spowija dana sytuację. (...) Inaczej mówiac, sytuacja napiętnowana przez jakościowa atmosfere uczuciowa (np. strachu) wyzwala określone intencje motoryczne, za pomoca których podejmujemy działanie, które np. może zmierzać do ucieczki z sytuacji lub do jej przeksztalcenia ${ }^{20}$.

Rozpowszechnione są dwa przeciwne podejścia do definiowania strachu. Pierwsze ujawnia ten stan emocjonalny jako źródło solidarności ${ }^{21}$, podczas gdy drugie zakłada, że strach ma tendencję do dzielenia ludzi. Jego zwolennikiem jest Jan Kracik, który - opisując reakcje staropolskiej ludności, gdy strach pojawiał się z powodu zagrożeń wojennych, pożarów, klęski żywiołowej itp. - dowodzi: Komplikowaty sie sprawy zwyczajne, rosty napięcia, wynaturzaty się relacje między ludźmi. Nieufność utrudniała kontakty, lęk rwat więzi społeczne, instynkt samozachowawczy zmagat się z gotowościa ratowania drugich ${ }^{22}$.

Małgorzata Szatan, odwołując do pracy Józefa Kozieleckiego „Psychologia nadziei”, określa negatywne i pozytywne funkcje strachu: Pozytywne funkcje sprowadzaja sie do traktowania strachu jako ostrzeżenia przed zagro-

16 U. Beck, Spoleczeństwo ryzyka, Warszawa 2004, s. 65.

17 Ю. М. Лотман, О семиотике понятий «стылд» $и$ «трах» в механизме культуpbl, [в:] Статьи по семиотике культуры и искусства, Санкт-Петербург 2002, с. 435.

18 A. Kępiński, Lęk, Warszawa 1977, s. 145.

19 Tamże, s. 146.

20 P. Duchliński, Atmosfera strachu $i$ jej rola $w$ doświadczeniu świata realnego, [w:] Anatomia strachu. Strach, lęk i ich oblicza we wspótczesnej kulturze, Kraków 2017, s. 131.

21 U. Beck, Spoleczeństwo..., s. 65.

22 J. Kracik, Pokonać czarna śmierć: staropolskie postawy wobec zarazy, Kraków 1991, s. 5 . 
żeniem, sygnału alarmowego, który umożliwia podjęcie określonych działań majacych na celu zapewnienie bezpieczeństwa, ponadto strach może motywować do działania, mobilizować do odpowiedniego przygotowania się do zadań, o których ewentualne niepowodzenie sie obawiamy. Funkcja negatywna będzie wiazać się z nieprzyjemnymi reakcjami organizmu, a takize odnosić do faktu, iż w przypadku nieadekwatnego do zagrożenia poziomu strachu/lęku może on sktaniać do podejmowania nieracjonalnych działań lub paraliżować wszelkie działania ${ }^{23}$.

Pozytywne funkcje strachu w ujęciu motywacji do działań przekładają się na dziedzinę kultury jako funkcje przede wszystkim kulturotwórcze. Natomiast negatywne funkcje odzwierciedlają się w stopniowej degradacji przez stagnację wszelkich aktywności kulturowych.

Pandemia niesie ze sobą chorobę, która jako zjawisko kojarzace się z rozpadem, destrukcja, a takize ze śmiercia (co pokazuja takíe dane etymologiczne), budzi lęk, który musi zostać skutecznie oswojony24. Strategie oswajania strachu są zbieżne z mechanizmami obronnymi, na których koncentruje się Karen Horney przy badaniach stanów neurotycznych. Zdaniem autorki, mechanizmy obronne są tak samo wszechobecne, jak i sam strach, występują one w różnych formach w każdej kulturze, spowodowane są specyficznymi warunkami życia charakterystycznymi dla tej kultury i mogą być przekształcone w niej w reguły ${ }^{25}$.

Strach przed pandemią jest głęboko zakorzeniony, archetypowy, ponieważ nie zmienia się ani w czasie, ani w przestrzeni, jak również nie zmieniają się strategie oswajania niebezpieczeństwa, które wiążą się z przeciwstawianiem się strachowi i tworzeniem akceptowanych jego form. Jest to skutecznym sposobem, pozwalającym nie tylko na zapobieganie negatywnym konsekwencjom, ale również na wykorzystanie „energii” strachu do wspierania kultury w momencie kryzysowym.

W literaturze przedmiotu strategie oswajania strachu najczęściej ujawniają się jako modele zachowań i reakcji zarówno społecznych jak i indywidualnych. Na przykładzie modeli zachowań w czasach dżumy w Europie zostało wyodrębnionych kilka stereotypowych wzorów reakcji społecznych w sytuacji zagrożenia. Są nimi dezintegracja dotychczasowych norm zachowania, m.in. niezwykła brutalizacja obyczajów, ratowanie własnego życia

23 M. Szatan, Strach a lęk w ujęciu nauk humanistycznych, „Studia Gdańskie” 2012, tom 31 , s. 326 .

24 M. Marczewska, Ja cię zamawiam, ja cie wypędzam...: choroba: studium językowo-kulturowe, Kielce 2012, s. 112.

25 К. Хорни, Невротическая личность нашего времени, Nykoping 2016, с. 14, 20. 
za wszelką cenę, zanik uczuć pozytywnych i empatii, rozpusta i pijaństwo, skrajna agresja, w tym - autoagresja oraz integracyjne sposoby tłumienia lęku - wspólny śpiew ${ }^{26}$, działający kojąco na ludzi, na otoczenie, zachowanie dystansu dzięki poczuciu humoru itp. ${ }^{27}$ Indywidualne sposoby tłumienia lęku mało czym różnią się od mechanizmów społecznych, oprócz tego, że zyskują szczytowy poziom emocjonalny w postaci maksymalnej agresji, nadmiernej dezintegracji lub nadmiernej integracji. Do nich należy także uzyskanie dystansu dzięki poczuciu humoru i postawie transcendentnej wobec własnego życia, gdyż staję się ono niekoniecznie wartością najwyższą, na skutek czego lęk przed śmiercią poddaje się redukcji ${ }^{28}$. Badacze wskazują też cztery wzory zachowań cechujących sytuacje kryzysowe wywołane środowiskiem naturalnym: ignorowanie i odrzucanie ryzyka, nie uświadomienie zagrożenia; pasywne liczenie się z możliwością zagrożenia i akceptowanie ewentualnych strat; przygotowywanie się do nadejścia kataklizmu, podjęcie działań zapobiegawczych w celu zredukowania strat; zmiana warunków życia pod wpływem powtarzających się kataklizmów ${ }^{29}$.

W kulturze ludowej wykształciły się strategie walki ze strachem i epidemią. Przeprowadzanie na przykład magicznych zabiegów ochronnych przed chorobami epidemicznymi miało zabezpieczyć człowieka i oswojoną przez niego przestrzeń - dom, podwórko, bądź wieś ${ }^{30}$. Za równie skuteczne w takich sytuacjach uważano stosowanie środków różnorakiego pochodzenia, jak również praktykowanie rytuałów leczniczych. Folklor zna też liczne wierzenia dotyczące przepowiadania nadejścia zarazy, które spowodował strach przed chorobami epidemicznymi ${ }^{31}$.

W filozoficznych analizach lęku egzystencjalnego podkreśla się, że mechanizmem obronnym przed nim staje się dobrowolna rezygnacja z swojej wolności na rzecz innych, oparcie na relacjach społecznych i wdrażanie idei ważnych dla wspólnoty i jednoczących ją ${ }^{32}$. Wspólnotowość przeżywa-

\footnotetext{
26 Przykładem takiego śpiewu jest wspólny śpiew mieszkańców włoskich miast podczas lockdownu narodowego wiosną 2020 roku, gdy ludzie na balkonach swoich mieszkań śpiewali piosenki - od folklornych ("Cantodella Verbena”) po utwory muzyki popularnej ( „Macarena”) i arie operowe.

27 A. Kępiński, Lęk..., s. 146-147.

28 Tamże, s. 147.

29 I. Burton, R. W. Kates, G. F. White, The Environment as Hazard, New York-London 1993, pp. 121-124.

30 M. Marczewska, Ja.., s. 175.

31 Tamże, s. 163, 183, 186.

32 J. Kutnik, Wielowymiarowość egzystencjalnego lęku - filozofia egzystencjalna jako inspiracja, [w:] Anatomia strachu. Strach, lęk i ich oblicza we współczesnej kulturze, Kraków 2017, s. 109.
} 
nia emocji lękowych w pewnym sensie rytualizuje strategie odnajdywania siebie w sytuacji zagrożenia, co jest szczególnie charakterystyczne dla kultury tradycyjnej, a więc i dla dziedzictwa niematerialnego, opierającego się $\mathrm{w}$ swojej istocie na tradycji w jej szerokim ujęciu. Dlatego wiele środków ludowych stosowanych podczas epidemii z reguły rozszerzało swoje właściwości ochronne na całą wspólnotę i wymagało udziału całej wspólnoty w ich aktualizacji. Zbiorowe działania na tle zagrożenia zewnętrznego, z jednej strony, opierają się na tożsamości zbiorowej wspólnoty, zaufaniu do zgromadzonego wspólnego doświadczenia pokoleń poprzez ujawnienie w rytuale zbiorowej pamięci kulturowej. Z drugiej zaś strony, kolektywność kształtuje tożsamość na podstawie wspólnego celu - chęci ochrony życia.

W odniesieniu do dziedzictwa niematerialnego punktem wyjściowym dla analizy działań spowodowanych strachem przed pandemią jest koncepcja jego ochrony sformułowana w Konwencji UNESCO z 2003 r. Zgodność z Konwencją może stać się pozytywnym wskaźnikiem oceny strategii. Strategie, służące realizacji założeń tej koncepcji, wynikają z pozytywnego traktowania strachu i sytuacji zagrożenia, czyli ich integrującego potencjału. Natomiast negatywne intencje strachu będą odzwierciedlać się w zawieszeniu aktywności kulturowych oraz rezygnacji z działań.

\section{Dziedzictwo niematerialne a pandemia}

Stosowanie środków zapobiegających rozprzestrzenianiu się COVID-19 (kwarantanna, izolacja, zachowanie dystansu społecznego) wpływa na poszczególne elementy niematerialnego dziedzictwa, wydarzenia, których zadaniem jest transmisja wiedzy tradycyjnej. Ulegają one transformacji, związanej z: a) przesunięciem na inny (nietradycyjny) termin poza zwyczajowe ramy czasowe oraz z przesunięciem w przestrzeni lub odwołaniem; b) odbywaniem się w trybie skróconym.

Przykładem pierwszego modelu zmian jest Ogólnopolski Festiwal Kapel i Śpiewaków Ludowych w Kazimierzu (OFKŚL) - wydarzenie organizowane od 1966 r. przez Wojewódzki Ośrodek Kultury w Lublinie w celu promowania kultury ludowej. Podczas imprezy przedstawiają swoje umiejętności artyści ludowi, prezentując najlepsze przykłady folkloru muzycznego z poszczególnych regionów Polski ${ }^{33}$. Szczególne znaczenie festiwalu podkreśla

33 A. Sar, O genezie i historii Ogólnopolskiego Festiwalu Kapel i Śpiewaków Ludowych w Kazimierzu Dolnym nad Wista, [w:] Muzyka najbliższa ziemi...: 50 lat Ogólnopolskiego Festiwalu Kapel i Śpiewaków Ludowych w Kazimierzu nad Wisła, Lublin 2016, s. 15. 
wpisanie go w 2020 roku do Krajowego rejestru dobrych praktyk na rzecz ochrony niematerialnego dziedzictwa kulturowego. Zwykle odbywa się on w ostatni weekend czerwca, jednak w $2020 \mathrm{r}$. był przeprowadzony dwa miesiące później - 28-29 sierpnia.

Z kolei Festiwal Sztuki Ludowej „Berahinia” - jedyny na Białorusi artystyczny projekt, skierowany na tradycyjne formy sztuki ludowej, szerokie zaangażowanie dzieci i młodzieży oraz wsparcie depozytariuszy - został odwołany na trzy tygodnie przed rozpoczęciem w czerwcu $2020 \mathrm{r}$. i przesunięty na rok 2021, mimo tego, że odbyły się wszystkie etapy przygotowawcze oraz regionalne eliminacje festiwalowe w kraju. Odwołanie festiwalu z 20-letnią historią ma negatywny wpływ na jego systemowość, która stanowi jedną z głównych konceptualnych podstaw wydarzenia. Festiwal jest celem, do którego dąży wiele osób, przygotowując się do udziału w turniejach i konkursach, targach twórczości ludowej, konferencji i debaty oraz do tradycyjnego święta „Рудабельскае Купалле” („Rudabielska Noc Kupalna”). Ciągłości praktyki grozi więc ryzyko przerwania zaangażowania depozytariuszy. Przesunięcie o rok generuje wiele kłopotów dla uczestników, którzy z reguły są podzieleni na grupy wiekowe: 9-11, 12-14, 15-18, 19-31, 32-40 lat i grupę po 41 roku życia ${ }^{34}$, gdyż, za rok będą musieli przejść do starszej grupy, co wiąże się z potrzebą opanowania nowych umiejętności na potrzeby prezentacji podczas festiwalu.

Według drugiego modelu zmian dotyczaccych dziedzictwa niematerialnego z powodu sytuacji epidemiologicznej, był poddany obrzęd na święto Jurja we wsi Pahost (rejon Żytkawicki, Białoruś) - musiał ulec skróceniu. Jedno z głównych świąt kalendarza ludowego - dzień św. Jurja (Jerzego) 6 maja - w 2020 r. miało być obchodzone podczas pierwszej fali pandemii. Doroczna praktyka obrzędowa, która jest symbolicznym otwarciem ziemi, gleby, zapowiada obfite zbiory, bogate i zdrowe życie w roku gospodarczym, była skrócona pod względem czasu trwania, zachowując swoją tradycyjną strukturę, na którą składa się etap przygotowawczy w przededniu (przygotowanie odświętnych strojów, pieczenie korowaju), etap główny (sama procesja do pola przy końcu wsi, korowód po polu, powrót do wioski i korowody oraz tańce przy posesjach mieszkańców) i etap końcowy (wspólna biesiada). Zarazem wszystkie materialne atrybuty obrzędu - gwiazda betlejemska, ikona, korowaj, grabie, fartuch zielony i czerwony, choragwie - były wykorzystywane, ponieważ mają głębokie symboliczne znaczenie i spełniają

34 Рэкамендацыі па арганізацыі і правядзенні XI Рэспубліканскага фестывалю-конкурсу фальклорнага мастацтва "Берагіня" 2019-2020, [online], https://kulturaokt.by/ -lr/42-2012-01-2411-09-17/820-2020-02-27-11-59-05.html, [dostęp 12.11.2020]. 
istotne funkcje na każdym etapie obrzędu. Skróceniu poddana była liczba uczestników procesji - w obchodzie brali udział jedynie mieszkańcy wsi i kilku dziennikarzy, choć z reguły w dniu uroczystości do Pahosta przyjeżdżają mieszkańcy okolicznych miejscowości, osoby zainteresowane z innych części kraju i tłumy przedstawicieli mediów. Specjaliści z dziedziny kultury, którzy opiekuja się tym obrzędem, oceniaja pozytywnie kontynuację tradycji mimo zagrożenia, biorąc pod uwagę fakt, że członkowie społeczności lokalnych, zwłaszcza w małych wsiach, są na co dzień ze sobą w kontakcie: Калі збіраліся ўсё ж мясцовыя супольнасчі для правядзення абраду, то паміж сабой яньь і так кантактуюиь. I, атрымліваециа, пагрозы захварэчь менш, таму што гэта і так кола, у якім яны заўсёды ёсць (Homel IH 2020 TM).

Podobna sytuacja miała miejsce podczas tegorocznego obchodu Bożego Ciała w Spycimierzu (województwo łódzkie, Polska). Obchody w tej miejscowości mają szczególną oprawę, ponieważ towarzyszy im tradycja układania kwietnych dywanów na całej długości trasy procesji. W wywiadach, przeprowadzonych z depozytariuszami tradycji w 2020 r., padały hasła „inaczej”, „,zzegoś brakowało”, „inaczej, ale też pięknie” (Spycimierz KW 2020 KS), „było pięknie”, „zupełnie inne doświadczenie” (Spycimierz ZG 2020 KS), „skromna”, „mało uroczyście” (Spycimierz ZG 2020 KS). Przygotowanie do uroczystości trwało jak zwykle i spycimierzanie poświęcili tyle samo pracy, jak w warunkach przedpandemicznych. Odmienność święta polegała na mniejszej liczbie uczestników (miejscowych i przybyłych), co wcale nie przeszkadzało społeczności lokalnej: Mi to nie przeszkadza w ogóle, ja jestem zadowolony, bo kto wie czy ktoś by nie przywiózt tego wirusa, a mam nadzieję, $\dot{z}$ e sie obyło bez zachorowań tutaj, po prostu ja wole takie kameralne, bo kiedyś to było kameralne święto, tylko gmina to obchodziła, a teraz cała Polska, każdy chce coś wnieść do tego święta (...) (Spycimierz KG 2020 AJ). Główna zmiana, której doświadczyli spycimierzanie, była zmianą przestrzenną: kwietne dywany układane zazwyczaj we wsi na szlaku procesji eucharystycznej i łączące się w jeden kobierzec o długości $2 \mathrm{~km}$ i szerokości ok. $2 \mathrm{~m}^{35}$, w 2020 r. miały o wiele mniejszą skalę: trasa procesji Bożego Ciała prowadziła wokół kościoła, co spowodowało, że kwiatowe wzory miały pomieścić się na o wiele mniejszej przestrzeni. Uległy zmianie i same dywany, które przez nadmiar kwiatów i małe pola do sypania, układano grubsze, „wypasione bardziej" (Spycimierz TP 2020 KS).

35 B. Włodarczyk, Przestrzeń sacrum i profanum $w$ trakcie uroczystości Bożego Ciała w Spycimierzu, [w:] Procesja Bożego Ciała z tradycja kwietnych dywanów w Spycimierzu Raport z badań $i$ rekomendacje do planu ochrony, Uniejów-Wrocław 2020, s. 103. 
Stosunek mieszkańców do zmian w tradycji jest niejednoznaczny. Niektórzy Spycimierzanie zaakceptowali zmiany, gdyż dla nich jest ważny sam fakt kontynuacji tradycji: Jak na te warunki, to wyszło wszystko. Dywany byty $i$ to solidne, no krótsze na pewno, ale ważne, $\dot{z} e$ byty (Spycimierz MP 2020 KS), inni odmówili udziału: Nie wszyscy ci, którzy zawsze uktadali dywany przy swoich posesjach, uczestniczyły $w$ tym roku, ale wróca (Spycimierz SP $2020 \mathrm{KS}$ ), niektórzy odetchnęli z ulga, że zaraz odpoczna, ale myśmy poszli (Spycimierz AW 2020 KS). Jeszcze inni uważają, że mimo tego, że wszystko się udało, ten element niematerialnego dziedzictwa stracił swój tradycyjny wydźwięk: A tu nie było tej tradycji. Ale jestem zadowolona, że wyszło jak wyszło (Spycimierz JR 2020 AWB), (...) dla nas to troche smutne święto. Jakoś tak nam trudno się z tym pogodzić, że jednak nie jest to tak tradycyjne (Spycimierz ZG $2020 \mathrm{KS}$ ).

W wymienionych przykładach forma tradycji została dostosowana do obecnych warunków, co jednak nie zmieniło duchowego meritum elementów niematerialnego dziedzictwa, pokazuje przewagę metafizycznych właściwości takiego dziedzictwa. Transformacja nie dotknęła najbardziej wartościowych dla tradycji składników, zarazem one stały się bardziej widoczne, ponieważ na pierwszy plan hierarchii wartości, która kształci się podczas sytuacji kryzysowych, „strasznych”, wysuwają się wartości, których utrata będzie mieć poważne skutki, wartości stanowiące istotę życia: Czasem dopiero poprzez atmosfere strachu uświadomimy sobie, w obliczu potencjalnej utraty jakiegoś dobra, jak wielka ma ono wartość dla naszego życia ${ }^{36}$ i wskazujące na istotę człowieka, który doświadcza siebie w sytuacjach granicznych, wtedy, gdy jego byt jest zagrożony ${ }^{37}$. Ingerując $\mathrm{w}$ format świąt, pandemia przywróciła pierwotne warunki funkcjonowania tradycji jedynie w wąskim kręgu wspólnot lokalnych, odsunęła na plan dalszy elementy niepotrzebne, zachowując to, co obiektywnie prezentuje wartość tradycji dla wspólnoty. Na to zwracają uwage depozytariusze dziedzictwa i specjaliści z dziedziny kultury zarówno w Polsce, jak i na Białorusi: (...) bardziej było, jak by to powiedzieć, po Bożemu, nie bylo takich - tak, jak w zgromadzeniu - przepychanek (Spycimierz MW 2020 KS); Тое, што было мала людзей, нават вельмі спадабалася самім носьбітам, таму што не заміналі праводзічь [абрад - аўт.] $i$ гэта было добра, бо тая сітуачьля пасадзейнічала больш спакойнаму павядзенню абрада (Homel IH 2020 TM).

\footnotetext{
36 P. Duchliński, Atmosfera..., s. 134.

37 Sytuacja graniczna według Karla Jaspersa jest sytuacją, gdy człowiek doświadcza walki, cierpienia, winy, śmierci. Zob.: K. Jaspers, Filozofia, Toruń 2020, s. 302, 303.
} 
Zaangażowanie depozytariuszy w działania służące kontynuowaniu tradycyjnych praktyk podczas pandemii COVID-19 podkreśla, że są one ważnym elementem tożsamości społeczności lokalnych i nadaje nowe znaczenie samym tradycjom, w tym wspomagają oswajaniu strachu przed aktualnymi zagrożeniami. Dla depozytariuszy niematerialnego dziedzictwa tradycyjne praktyki w czasach kryzysu są sposobem na rozładowanie stresu, dzielenie się zmartwieniami w gronie osób o podobnych zainteresowaniach. Dążenie do tradycji w trudnych warunkach stabilizuje wspólnotę, wzmacnia jej wewnętrzne więzi, tradycja bowiem jest jedną ze stałych cech życia wspólnoty lokalnej. Z jednej strony, wspólnotowość pomaga w przeżywaniu strachu, ułatwia go opanowanie na podstawie wymiany doświadczeń traumatycznych, podtrzymuje na duchu, spełnia funkcję terapeutyczną. W grupie człowiek czuje się bezpieczny, kontakt z innymi zmniejsza napięcia lękowe: Uczucia, które w przestrzeni własnej nabieraja nieraz katastroficznych proporcji, maleja, gdy wejdzie się we wspólna przestrzeń, staja się łatwiejsze do zniesienia, a nawet zmieniaja swój znak z ujemnego na pozytywny ${ }^{38}$. A z drugiej strony, sam strach jednoczy, zachęca do tworzenia wspólnoty, tworzy spójność i harmonijność przy wspólnym spędzaniu czasu: Ale dzisiaj chociażby to, że jest ten koronawirus, spotykamy sie razem, żeby potkać, porozmawiać. Jest ta przyczyna, dla której się spotykamy. Jest wtedy raźniej, wiara $w$ coś $i$ zreszta sama taka praca, jak siadam przy krosnach, to mnie to ogromna radość sprawia. Ja się wyłaczam ze wszystkich swoich problemów, terapeutyczna rola. I wtedy ja się koncentruje na tym, co robie, i taka mam radość wewnętrzna (Husinka BPM 2020 TM).

Poza stabilizacją życia, powodem do kontynuowania tradycji stało się rozumienie przez depozytariuszy znaczenia dziedzictwa dla społeczności lokalnej i świadomość tego, że muszą ciągle być w procesie - przekazywać wiedzę pokoleniom młodszym i uczyć się od pokoleń starszych, zwłaszcza biorąc pod uwage najstarszych wiekiem depozytariuszy. Model przekazywania tradycji mistrz - uczeń jest charakterystyczny dla pereborów nadbużańskich - techniki tkackiej polegającej na powstawaniu wzoru na tkaninie płóciennej przez wybieranie deseczką na osnowie i przetykanie kolorowym wątkiem ${ }^{39}$. Tradycje tkackie zostały w 2016 roku wpisane na Krajową listę niematerialnego dziedzictwa kulturowego Polski. Rozpowszechnione są na terenach północno-wschodniej Lubelszczyzny, wschodu województwa

\footnotetext{
38 A. Kępiński, Lęk..., s. 55.

39 B. Pawlina-Maksymiuk, Perebory. Nadbużańskie tradycje tkackie, Husinka-Drelów 2019, s. 5 .
} 
Podlaskiego oraz na Białorusi i Ukrainie ${ }^{40}$. Perebory znajdują się w centrum uwagi Fundacji Nadbużański Uniwersytetu Ludowego - placówki edukacji dorosłych, która prowadzi pracownie ginących zawodów, m.in. tkactwa. Uniwersytet jednoczy wokół siebie tkaczki różnych pokoleń. Podczas pandemii nauczanie pereborów trwało z potrzeby ciągłej transmisji: nie możemy przestać, bo pani Stasia ma 80 lat. To jest czas, który nam umy$k a$, (...) Kontakt jest ciagly, ponieważ nie chcemy przerwać tego procesu (Husinka BPM 2020 TM). Tkaczki nieustannie zajmowały się rekonstrukcją starożytnych wzorów ludowych, poszukując ich ostatnich ocalałych w regionie fragmentów: jeździłam po obszarze nadbużańskim, opisywałam wzory (Husinka BPM 2020 TM). Jak z tego wynika, że oswajanie strachu przed pandemią dotyczy sfery dziedzictwa niematerialnego, które, z jednej strony, jest zagrożone $\mathrm{z}$ tego względu, że ze swej istoty opiera się na bezpośredniej komunikacji depozytariuszy, utrudnionej w warunkach zagrożenia pandemicznego, a z drugiej - samo służy opanowaniu przeżyć traumatycznych, ponieważ wspólna kulturowa tradycja pomaga opanować traume, a czerpanie $z$ tradycji folklorystycznej wzmacnia wartość wsparcia społecznego ${ }^{41}$. Zatem dziedzictwo niematerialne jednoczy na podstawie wspólnego niebezpieczeństwa i służy rozładowaniu stresu.

\section{Instytucjonalny wymiar ochrony dziedzictwa a pandemia}

Środowisko instytucjonalne radzi sobie w warunkach pandemii dzięki różnorodnym strategiom, którymi są zmiany narzędzi ochrony niematerialnego dziedzictwa i dopasowanie swych czynności. W opiekę nad niematerialnym dziedzictwem kulturowym jest zaangażowany na przykład Wojewódzki Ośrodek Kultury w Lublinie (WOK). Do zakresu funkcji WOK należy animacja kulturalna, wspieranie amatorskiej twórczości artystycznej i ochrona tradycji i dziedzictwa kulturowego ${ }^{42}$. Po pojawieniu się pandemii zmieniony został sposób działania instytucji, co stało się konsekwentną potrzebą dostosowywania się do nowej normalności, i przede wszystkim do ograniczeń.

\footnotetext{
40 A. W. Brzezińska, A. Paprot, M. Tymochowicz, Klocki, snutki, perebory: tradycyjne rękodzieło wobec wyzwań wspótczesności, Wrocław 2015, s. 17.

41 J. Hajduk-Nijakowska, Żywiol i kultura. Folklorystyczne mechanizmy oswajania traumy, Opole 2005, s. 226.

42 Fragmenty Statutu Wojewódzkiego Ośrodka Kultury, [online], http://www.wok.lublin.pl/ index.php?item=o-nas, [dostęp 05.12.2020].
} 
Zastrzeżenia dotyczące dystansu społecznego doprowadziły do odwołania wydarzeń i przeniesienia niektórych działań edukacyjnych, promocyjnych i animacyjnych WOK do świata wirtualnego. Zrezygnowano z II Wojewódzkiego Konkursu na Palmę i Pisankę Wielkanocną; nie odbyły się wojewódzkie eliminacje OFKŚL, które miały zacząć się późną wiosną w poszczególnych powiatach. W celu popularyzacji kultury przygotowano materiały metodyczne i umieszczono je do pobrania na stronie internetowej Ośrodka. W okresie Wielkanocy powstała wirtualna Galeria Wielkanocna ${ }^{43}$, która stała się platformą do dzielenia się zdjęciami koszyka wielkanocnego, palm i pisanek nietypowej Wielkanocy 2020 roku. Propozycja ta miała na celu angażowanie osób, które poczuły się wyobcowane oraz przywrócenie wspólnego doświadczania w warunkach atmosfery świąt w małym gronie w sytuacji odwołania tradycyjnego święcenia pokarmów w kościołach.

Internet jest narzędziem, które przy komunikacji zdalnej pomaga podejmować działania, ale jednak nie zawsze w pełni odpowiada grupie docelowej. Działania w sferze kultury ludowej z reguły opierają się na wspólnotowości, jak na przykład wydarzenia typu przeglądy, spotkania, festiwale. Tak więc coroczny Ogólnopolski Festiwal Kapel i Śpiewaków Ludowych organizowany przez lubelski WOK, odbył się w środowisku realnym. Istniało ku temu kilku powodów. Po pierwsze, OFKŚL daje możliwość samospełnienia artystom ludowym. Dla wielu osób był praktycznie jedynym wydarzeniem tego typu w 2020 roku. Festiwal odbył się w stosunkowo bezpiecznym okresie - w sierpniu, gdy pandemia przycichła, jednak mimo tego był wyzwaniem i dla organizatorów, i dla uczestników. Po drugie, tegoroczna edycja festiwalu była edycja 54., a zatem kontynuowanie festiwalu już samo w sobie jest zachowaniem ciągłości i tradycją, która wymaga dbałości i regularnej praktyki. Po trzecie, organizacja festiwalu była niezwykle ważna dla WOK, ponieważ jest on imperatywem do działania (Lublin AS 2020 TM) dla instytucji, wiąże się z aktywnością, która jest niezbędna w czasie kryzysu.

OFKŚL doświadczył transformacji według modelu skróconego. Zmiany były związane z koniecznością zachowania procedury bezpieczeństwa, „zamknięciem” sceny festiwalowej (przesłuchania zostały ulokowane w dużym ogrodzonym namiocie), wyeliminowaniem masowych wydarzeń programowych, które polegały na rezygnacji z dodatkowych działań dotyczących

43 Galeria Wielkanocna, [online], http://www.wok.lublin.pl/index.php?item=galeriawielkanocna, [dostęp 05.12.2020]. 
rozrywkowego wymiaru wydarzenia - zabawy ludowej na rynku i tzw. pograjek w klubie festiwalowym, korowodu otwierającego festiwal, mszy świętej oraz uroczystego zakończenia OFKŚL. Zachowując dystans społeczny przeprowadzono warsztaty rękodzielnicze, lecz zrezygnowano z warsztatów tańca ludowego, który jest tańcem kontaktowym. Niezbędnym elementem festiwalu są Targi Sztuki Ludowej organizowane z roku na rok przez Stowarzyszenie Twórców Ludowych w Lublinie. Zważywszy na zasady bezpieczeństwa epidemicznego, w Targach wzięło udział o połowę mniej mistrzów ludowych, niż zazwyczaj. Mniejsza liczba uczestników pozytywnie wpłynęła na jakość wystawionych prac: Co się okazało, że twórcy przywieźli w tym roku [2020 - aut.] wyjatkowo dobre prace na bardzo wysokim poziomie. Bogactwo tych prac było naprawde olbrzymie (Lublin PO 2020 TM).

Nowe warunki i zmiany zostały zaakceptowane przez uczestników i widzów festiwalu jako wynik kompromisu pomiędzy dwiema aspiracjami kulturotwórczą, popędem życia (Eros) a destrukcyjną, popędem śmierci (Tanatos) - wywołanymi strachem: I ludzie to zaakceptowali. Okazuje sie, że ludzie sa tolerancyjni, jeśli chodzi o tego typu zmiany, akceptuja to, nie było żadnych głosów niechęci. To było przełamanie bariery, lęku, strachu (Lublin AS 2020 TM).

Strona konkursowa festiwalu, która w zasadzie stanowi o zachowaniu tej transmisji [dziedzictwa niematerialnego - aut.] i niesie role kulturotwórcza (Lublin AS 2020 TM), nie uległa transformacji. Ograniczenia nie były stosowane ani do ilości uczestniczących wykonawców, ani do programu i regulaminu konkursowego. A więc występując w wersji skróconej, wymuszonej przez konieczność spełnienia kryteriów sanepidu, festiwal zademonstrował swoją istotę.

Na Białorusi, przez brak oficjalnie ogłoszonych ograniczeń podczas pierwszej fali pandemii, działalność poszczególnych instytucji i organizacji zależała od decyzji jej administracji. Natomiast jesienią 2020 r. sytuacja się zmieniła: od 5 listopada w kolejnych regionach kraju stopniowo wprowadzono zasadę noszenia maseczek w miejscach publicznych, na poziomie państwowym zalecano odwoływanie imprez masowych, a jeśli to nie jest możliwe, muszą być koniecznie przestrzegane zasady bezpieczeństwa epidemiologicznego. Te ograniczenia miały bezpośredni wpływ na działalność instytucji kultury.

Zachowaniu kultury ludowej na Białorusi od 1939 r. służy jedno z sześciu regionalnych centrów - Regionalne Centrum Twórczości Ludowej w Homlu (RCTLH). Zadaniami ośrodka jest m.in. wsparcie i promowanie niematerialnego dziedzictwa oraz przygotowanie nominacji do wpisu na Krajową listę dziedzictwa historyczno-kulturowego Republiki Białoruś. Działalność 
centrum od wiosny 2020 r. była ograniczona zasadami bezpieczeństwa epidemiologicznego. Zostały odwołane wyjazdy terenowe pracowników Centrum $\mathrm{w}$ trosce o zdrowie przedstawicieli społeczności lokalnych: каб не заразіџь сябе і тых людзей [depozytariusze - aut.] (Homel IH 2020 TM). Przeniesiono na terminy nieokreślone lub odwołano ogólno białoruskie wydarzenia, których RCTLH jest współorganizatorem (np. Festiwal „Berahinia”). Jednakże zostały organizowane wystawy utworów sztuki ludowej z udziałem depozytariuszy dziedzictwa niematerialnego - mistrzów i mistrzyń plecenia ze słomy, tkaczek z Niehlubki. Depozytariusze lokalnych stylów wykonania pieśni i tradycji obrzędowych uczestniczyli w wydarzeniach, organizowanych przez centrum w lecie, gdy sytuacja epidemiologiczna stosunkowo się ustabilizowała. Jedną z takich imprez był VI Międzynarodowy Festiwal Tradycji Etnokulturowych „Кліч Палесся” ( „Apel Polesia”, Laskowicze, rejon Pietrikowski, 29 sierpnia).

Niektóre formy dotychczasowej działalności RCTLH uległy zmianom. Monitoring stanu niematerialnego dziedzictwa w regionie od wiosny $2020 \mathrm{r}$. zaczęto prowadzić jedynie zdalnie: specjaliści Centrum otrzymują informacje od lokalnych ośrodków, potwierdzone zdjęciami. W strategii działania inicjatyw instytucji położono akcent na szerokie wykorzystanie mediów społecznościowych oraz rozwijanie własnego wizerunku poprzez działalność w Internecie, ponieważ: Інтэрнэт з'яўляециа інструментам прачь, які дапамагае рэалізойваць мэты нашай ўстановь (Homel IH 2020 TM). Środowisko wirtualne jest traktowane przez Centrum jako placówka do komunikacji, edukacji i promocji. Na stronie internetowej RCTLH umieszczone zostały nagrania warsztatów rzemieślniczych z robienia glinianej okaryny, drewnianej łyżki, ptaka ze słomy, wycinania z papieru, różnorakie informacje o elementach dziedzictwa niematerialnego wpisanych na Krajową listę dziedzictwa historyczno-kulturowego Republiki Białoruś oraz publikacje. Media społecznościowe są wykorzystywane również do promocji działalności Centrum i organizowanych przez nie wydarzeń.

W obwodzie homelskim znajduje się jeden z ośrodków perebornego tkactwa Białorusi - Centrum Tkactwa w Niehlubce. Tradycje tekstylne wsi Niehlubka są uznane za niematerialne dziedzictwo kulturowe kraju. Lokalne tkaczki posługują się różnymi technikami: pereborami (perebor „pod płótno", dwustronny i jednostronny perebor), „braną”, „wybraną”, „zakładną” i techniką wielowątkową. Z wykorzystaniem tych technik powstają ręczniki, elementy stroju ludowego, a także tekstylia do wnętrz (zasłony, obrusy i nawet koce). W Niehlubce aktywnie pracuje 5 mistrzyń starszego pokolenia. Przekazywanie tradycji w tej miejscowości odbywa się poprzez formalną i nieformalną edukację oraz w rodzinach. Wśród rodzin, gdzie tkactwo jest 
kultywowane od pokoleń, wyróżnia się rodzina Kowalowych. W transmisji wiedzy, związanej z tkactwem, uczestniczą trzy jej pokolenia - babcia Ludmiła Kawalowa, jej córka Elena oraz wnuki Anastazja, Konstantyn i Cyryl. Ludmiła Kawalowa jest kierowniczką pracowni tkackiej „Hiток” („Nitok”) przy wiejskim ośrodku tkackim w Niehlubce. Od wiosny 2020 r. prezentowała swoje umiejętności na imprezach regionalnych i lokalnych (święto „Купалле” („Kupalje”) w lipcu, rejon Szkłowski, obwód Mohylewski; regionalne dożynki we wrześniu, miasto Mozyr, obwód Homelski). Rodzina zdobyła nagrodę publiczności w maju 2020 r. w konkursie online na temat tradycji rodzinnych „Талент нараджаецца у с сям'i” („Talent rodzi się w rodzinie").

Pandemia wniosła do lokalnej tradycji dość osobliwą innowację. Depozytariuszki tkactwa zaczęły tworzyć maseczki ochronne. Maseczki są wykonane z płótna w tradycyjnych kolorach (czerwony, biały, czarny) z charakterystycznym geometrycznym wzorem. Interesujące jest to, że - dzięki tradycyjnej technice tkania, ornamentów i tradycyjnym kolorom - takie maseczki, zdaniem tkaczek, spełniają również funkcję apotropaiczną: Пpuилось взяться за изготовление обережных, многоразовых, защитных масок $^{44}$.

\section{Podsumowanie}

Strategie opanowania strachu przed pandemią i jej zagrożeniami w sferze dziedzictwa niematerialnego Polski i Białorusi można charakteryzować jako strategie adaptacyjne. Mieszczą się one w ramach generalnego podejścia do ochrony dziedzictwa niematerialnego, określonego w Konwencji UNESCO z 2003 r., adaptując do sytuacji pandemii narzędzia ochrony, którymi są identyfikacja, dokumentacja, badania, zachowanie, zabezpieczanie, promowanie, wzmacnianie i przekazywanie poprzez edukację formalną i nieformalną i rewitalizację różnych aspektów tego dziedzictwa ${ }^{45}$. Tak więc modyfikacja temporalnej organizacji codzienności przez pandemię pozwoliła na podejmowanie działań, dotyczących identyfikacji, inwentaryzacji

44 Komentarz, zostawiony przez Ludmiłę Kowalową depozytariuszkę niehlubskich tradycji tkackich w medium społecznościowe: https://ok.ru/profile/576272975584/album/8744 $87217120 / 895561793504$.

45 Konwencja w sprawie ochrony niematerialnego dziedzictwa kulturowego z 2003 r., sporzadzona w Paryżu dnia 17 października 2003 r., [online], http://www.unesco.pl/fileadmin/ user_upload/pdf/Konwencja_o_ochronie_dz._niemater_2003.pdf, [dostęp 15.12.2020]. 
i zabezpieczania dziedzictwa niematerialnego, ponieważ czas ograniczonych kontaktów społecznych okazał się czasem na przeszukiwanie strychów, na otwieranie jakichś kuferków, ogladanie zdjęć (Husinka MP 2020 TM). Zmiany więzi społecznych, które nastąpiły podczas pandemii, dla dziedzictwa przekazywanego w małym gronie, najczęściej w rodzinie, stały się powodem wzmacniania transmisji wiedzy i etnoedukacji: Bo mamy czy babcie miaty czas, dzieci zostawały w domu, trzeba było czymś zajać, nawet taka robótka na drutach czy na szydetku. Jak dziecko zaczyna coś tam robić, to potem tatwiej docenia to piękno, takie, co było kiedyś robione, dziedzictwo, te prace bardziej szanuje ręczna (Husinka MP 2020 TM). Skupienie się na życiu lokalnym i kulturze lokalnej, czy nawet mikrolokalnym - rodzinnym - uwydatniło znaczenie tożsamościowe dziedzictwa niematerialnego i uwypukliło rolę kultury małych wspólnot na skali krajowej. Ochrona tradycji była realizowana również przez rewitalizację jej poszczególnych regionalnych elementów przy pomocy pracy w terenie.

Strategie działań na Białorusi i w Polsce mają zarówno podobieństwa, jak i cechy odrębne. Z powodu rozbieżności oficjalnych podejść do walki $\mathrm{z}$ pandemią $\mathrm{w}$ obu krajach, ujawnia się przede wszystkim różnica $\mathrm{w}$ instytucjonalnej sferze ochrony dziedzictwa niematerialnego, dotycząca zasad bezpieczeństwa epidemiologicznego, wpływającego bezpośrednio na częstotliwość i liczbę odwołanych wydarzeń oraz na funkcjonowanie samych instytucji w czasie pandemii.

Z kolei podobieństwa mają wymiar pozytywny i negatywny. Na podstawie przeanalizowanych przykładów wyróżnia się strategia rezygnacją z działań, które mają na celu upowszechniania wiedzy o dziedzictwie i jego promowanie. Ostatecznie więc minimalizacja kontaktów bezpośrednich doprowadziła do zakłócenia transmisji praktyk tradycyjnych.

Do pozytywnego wymiaru należy stosunek depozytariuszy i społeczności lokalnych w dobie pandemii do swych tradycji. Nie uległ on zmianom, a nawet uległ wzmocnieniu przekaz dziedzictwa niematerialnego z pokolenia na pokolenie. Dla poszczególnych elementów tego dziedzictwa i wydarzeń organizowanych w celu jego ochrony w obu krajach stosowana jest dwumodelowa strategia transformacyjna. Model pierwszy opiera się na przesunięciu praktyk w czasie i przestrzeni lub ich odwołaniu. Model drugi zakłada skrócenie praktyk tradycyjnych i ma podtypy, które można wyróżnić w zależności od tego, co ulega skróceniu: bądź to wymiar czasowy, bądź wymiar przestrzenny, bądź zmniejszenie liczby osób. Oba modele transformacji mogą być stosowane w sposób hybrydowy i się łączyć. Internet i instrumenty multimedialne stały się podstawą strategii adaptacji i powszechnym narzędziem promocji i edukacji zarówno formalnej, jak i nieformalnej. Wymiarem 
pozytywnym również jest ich szerokie wykorzystywanie w celu popularyzacji dziedzictwa niematerialnego przez depozytariuszy i instytucje, zajmujące się ochroną dziedzictwa kulturowego. Skuteczność każdej strategii zależy od specyfiki zagrożenia, dotychczasowych warunków funkcjonowania wspólnot lokalnych i cech podmiotu, na który nakierowane są działania podejmowane $\mathrm{w}$ ramach strategii.

\section{Wywiady}

Homel IH 2020 TM - Iryna Hłuszec. ur. 1985, od urodzenia mieszka w Homlu, wiodaccy metodysta ds. etnografii i folkloru Regionalnego Centrum Sztuki Ludowej w Homlu, wywiad nagrany 1 grudnia 2020, eksploratorka, która przeprowadzała wywiad i transkrybowała T. Marmysh, AFTM ${ }^{46}$.

Husinka BPM 2020 TM - Bożena Pawlina-Maksymiuk, ur. 1954 w Radzyniu Podlaskim, przeprowadziła się do Husinki po studiach; założycielka Nadbużańskiego Uniwersytetu Ludowego, tkaczka; nagr. 9 października 2020, eksplor. i transkr. T. Marmysh, AFTM.

Husinka MP 2020 TM - Magdalena Papakul, ur. 1959, od urodzenia mieszka w Mordach, tkaczka; nagr. 10 października 2020, eksplor. i transkr. T. Marmysh, AFTM.

Lublin AS 2020 TM - Andrzej Sar, zastępca dyrektora ds. merytorycznych Wojewódzkiego Ośrodka Kultury, kierownik artystyczny Ogólnopolskiego Festiwalu Kapel i Śpiewaków Ludowych w Kazimierzu; nagr. 15 października 2020, eksplor. i transkr. T. Marmysh, AFTM.

Lublin PO 2020 TM - Paweł Onochin, koordynator zadań merytorycznych Stowarzyszenia Twórców Ludowych; członek redakcji kwartalnika „Twórczść Ludowa”; nagr. 22 października 2020, eksplor. i transkr. T. Marmysh, AFTM.

Spycimierz JR 2020 AWB - Joanna Rochoń, ur. w 1973, pochodzi ze Spycimierzu, mieszka w Warszawie od 1995 r. (wyjazd na studia); bierze czynny udział w tradycji nasypania kwietnych dywanów na Boże Ciało; nagr. 10 czerwca 2020 (Boże Ciało), eksplor. i transkr. A. W. Brzezińska, AMGBPU 47 .

Spycimierz KG 2020 AJ - Konstanty Górka, ur. 1996, od urodzenia mieszka w Kolonii Spycimierz; Społecznik, opisał w swojej pracy licencjac-

\footnotetext{
46 AFTM - Archiwum Folklorystyczne Tatsiany Marmysh.

47 AMGBPU - Archiwum Miejsko-Gminnej Biblioteki Publicznej w Uniejowie.
} 
kiej sypanie Kwietnych Dywanów; nagr. 11 czerwca 2020, eksplor. i transkr. A. Jełowicki, AMGBPU.

Spycimierz KW 2020 KS - Karolina Winnicka, ur. 1992, od urodzenia zam. w Spycimierzu; nagr. 11 czerwca 2020 (Boże Ciało), eksplor. i tranksr. K. Smyk, AFKS ${ }^{48}$.

Spycimierz NN 2020 AJ - Kobeta, NN, lat około 40, zamieszkała w Spycimierz - Kolonii, nagr. 11 czerwca 2020, eksplor. i transkr. A. Jełowicki, AMGBPU.

Spycimierz MW 2020 KS - Maria Winnicka, ur. 1956 w Spycimierzu, od urodzenia mieszka w Spycimierzu, w domu po rodzicach; nagr. 29 czerwca 2018, eksplor. i transkr. K. Smyk, AFKS.

Spycimierz SP 2020 KS - Stanisław Pełka, ur. 1952 w Spycimierzu; mieszka tu od urodzenia; sołtys Spycimierza od roku 1989; zakładał w 1970 r. orkiestrę dętą, która m.in. idzie w procesji Bożego Ciała; nagr. 12 czerwca 2020 (dzień po Bożym Ciele), eksplor. i transkr. K. Smyk, AFKS.

Spycimierz TP 2020 KS - Tadeusz Pełka, ur. 1950, od urodzenia zam. w Spycimierzu; nagr. 11 czerwca 2020 (Boże Ciało), eksplor. i transkr. K. Smyk, AFKS.

Spycimierz ZG 2020 KS - Zofia Górka, ur. 1959 w Spycimierzu, wiele lat mieszkała w Łowiczu, siostra Marii Winnickiej; nagr.: 11 czerwca 2020 (Boże Ciało), eksplor. i transkr. K. Smyk, AFKS.

\section{LITERATURA}

Beck U., Spoleczeństwo ryzyka, Warszawa 2004.

Bremier J. SJ, Co kognitywistyka może nam powiedzieć o lęku i strachu?, [w:] Anatomia strachu. Strach, lęk i ich oblicza we wspótczesnej kulturze, Kraków 2017.

Brzezińska A.W., Paprot A., Tymochowicz M., Klocki, snutki, perebory: tradycyjne rękodzieło wobec wyzwań wspótczesności, Wrocław 2015.

Burton I., Kates R. W., White G. F., The Environment as Hazard, New YorkLondon 1993.

Duchliński P., Atmosfera strachu $i$ jej rola $w$ doświadczeniu świata realnego, [w:] Anatomia strachu. Strach, lęk $i$ ich oblicza we wspótczesnej kulturze, Kraków 2017.

Fragmenty Statutu Wojewódzkiego Ośrodka Kultury, [online], http://www.wok. lublin.pl/index.php?item=o-nas, [dostęp 05.12.2020].

48 AFKS - Archiwum Folklorystyczne Katarzyny Smyk. 
Freud Z., Pisma społeczne. Dzieła, Warszawa 1998, tom IV.

Galeria Wielkanocna, [online], http://www.wok.lublin.pl/index.php?item=galeriawielkanocna, [dostęp 05.12.2020].

Hajduk-Nijakowska J., Żywioł i kultura. Folklorystyczne mechanizmy oswajania traumy, Opole 2005.

Horni K., Nevrotičeskâ̂ ličnost' našego vremeni, Nykoping 2016 [Хорни К., Невротическая личность нашего времени, Nykoping 2016].

Jaspers K., Filozofia, Toruń 2020.

Kępiński A., Lęk, Warszawa 1977.

Konwencja w sprawie ochrony niematerialnego dziedzictwa kulturowego z 2003 r., sporzadzona w Paryżu dnia 17 października 2003 r., [online], http://www. unesco.pl/fileadmin/user_upload/pdf/Konwencja_o_ochronie_dz._niemater_ 2003.pdf, [dostęp 15.12.2020].

Kracik J., Pokonać czarna śmierć: staropolskie postawy wobec zarazy, Kraków 1991.

Kutnik J., Wielowymiarowość egzystencjalnego lęku - filozofia egzystencjalna jako inspiracja, [w:] Anatomia strachu. Strach, lęk i ich oblicza we wspótczesnej kulturze, Kraków 2017.

Living Heritage Experiences and the COVID-19 Pandemic, [online], https://ich. unesco.org/en/living-heritage-experiences-and-the-covid-19-pandemic-01123, [dostęp 08.11.2020].

Living Heritage Experiences and the COVID-19 Pandemic: Snapshot of the UNESCO Online Survey, [online], https://ich.unesco.org/doc/src/8GA-snap shot_on_survey_living_heritage_pandemia-EN.pdf, [dostęp 29.11.2020].

Lotman Û. M., O semiotike ponâtij «styd» $i$ «strah» $v$ mehanizme kul'tury, [v:] Stat'i po semiotike kul'tury i iskusstva, Sankt-Peterburg 2002 [Лотман Ю. М., О семиотике понятий «стылд»и «страх»в механизме культурь, [в:] Статьи по семиотике культурь и искусства, Санкт-Петербург 2002].

MacKenzie D., COVID-19: pandemia, która nie powinna była się zdarzyć, i jak nie dopuścić do następnej, Poznań 2020.

Marczewska M., Jacię zamawiam, ja cię wypędzam...: choroba: studium językowo-kulturowe, Kielce 2012.

Pawlina-Maksymiuk B., Perebory. Nadbużańskie tradycje tkackie, Husinka-Drelów 2019 .

Procesja Bożego Ciała z tradycja kwietnych dywanów w Spycimierzu Raport z badań $i$ rekomendacje do planu ochrony, red. Katarzyny Smyk, Uniejów-Wrocław: Miejsko-Gminna Biblioteka Publiczna w Uniejowie, Polskie Towarzystwo Ludoznawcze, 2020.

Rèkamendacyì pa arganizacyì i pravâdzenni XI Rèspublikanskaga festyvalû-konkursu fal'klornaga mastactva "Beraginâ" 2019-2020, [online], https://kultura 
okt.by/-lr/42-2012-01-24-11-09-17/820-2020-02-27-11-59-05.html, [dostęp 12.11.2020] [Рэкамендачьі па арганізачьі і правядзенні ХІ Рэспубліканскага Фестьвалю-конкурсу Фальклорнага мастачтва "Берагіня" 2019-2020, [online], https://kulturaokt.by/-lr/42-2012-01-24-11-09-17/8202020-02-27-11-59-05.html, [dostęp 12.11.2020]].

Sar A., O genezie $i$ historii Ogólnopolskiego Festiwalu Kapel i Śpiewaków Ludowych w Kazimierzu Dolnym nad Wista, [w:] Muzyka najbliższa ziemi...: 50 lat Ogólnopolskiego Festiwalu Kapel i Śpiewaków Ludowych w Kazimierzu nad Wista, Lublin 2016.

Sitek W., Wspólnota i zagrożenie: wrocławianie wobec wielkiej powodzi: socjologiczny przyczynek do analizy krótkotrwałej wspólnoty, Wrocław 1997.

Smyk K., Obrzęd jako tekst kultury. Przykład Bożego Ciała w Spycimierzu, Wydawnictwo UMCS, Lublin 2020.

Sorokin P., Čelovek $i$ obŝestvo v usloviâh bedstvij. Vliânie vojny, revolûcii, goloda,

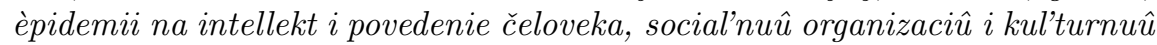
żizn' [Сорокин П., Человек и общество в условиях бедствий. Влияние войны, револючии, голода, эпидемии и на интеллект и поведение человека, соииальную организацию и культурную жизнь, Санкт-Петербург 2012].

Szatan M., Strach a lęk w ujęciu nauk humanistycznych, „Studia Gdańskie” 2012, tom 31 .

Ścibiorek Z., Uwarunkowania zachowań ludzkich w sytuacji zagrożenia, [w:] Społeczeństwo a wojna: oblicza bezpieczeństwa w XX i XXI wieku, Wrocław 2016.

Tuchman B., Odległe zwierciadto czyli rozlicznymi plagami nękane XIV stulecie, Katowice 1993.

Vovelle M., Śmierć w cywilizacji Zachodu: od roku 1300 po wspótczesność, Gdańsk 2004.

Włodarczyk B., Przestrzeń sacrum i profanum w trakcie uroczystości Bożego Ciata w Spycimierzu, [w:] Procesja Bożego Ciała z tradycja kwietnych dywanów w Spycimierzu Raport z badań i rekomendacje do planu ochrony, Uniejów-Wrocław 2020.

\section{SUMMARY}

\section{THE INTANGIBLE CULTURAL HERITAGE IN THE CONDITIONS OF THE COVID-19 PANDEMIC. COMPARATIVE ANALYSIS F SELECTED EXAMPLES FROM POLAND AND BELARUS}

The article discusses strategies to overcome the fear of the COVID-19 pandemic and its threats in the sphere of the intangible heritage in Poland and Belarus. The strategies are presented as activities that make an adaptive use of the measures for safeguarding recommended by the Convention for the Safeguarding of the Intan- 
gible Cultural Heritage 2003. Activities to maintain the viability of the intangible heritage have both similarities and differences in both countries. The difference is revealed in the institutional sphere of heritage safeguarding. The similarities have a negative dimension (resignation from actions, disruptions in the transmission of knowledge) and a positive dimension (a two-model strategy of transforming traditional practices, the use of the Internet and multimedia instruments).

Key words: intangible heritage, pandemic COVID-19, strategies, Poland, Belarus, 2003 Convention. 